\title{
Influence of the Environment on Cassava Quality Traits in Central Rift Valley of Kenya
}

\author{
John N. Ndung' ${ }^{1,2^{*}}$, Francis N. Wachira ${ }^{2}$, Miriam G. Kinyua ${ }^{3}$, David K. Lelgut ${ }^{1}$, Henry Okwaro $^{1}$, \\ Peter Njau ${ }^{1}$, Hannington Obiero ${ }^{4}$ \\ ${ }^{1}$ Kenya Agricultural Research Institute, KARI-Njoro, P.O. Private Bag, NJORO, Kenya; ${ }^{2}$ Department of Biochemistry and Molecular \\ Biology, Egerton University, Egerton, Kenya; ${ }^{3}$ Department of Biotechnology, Moi University, Eldoret, Kenya; ${ }^{4}$ Kenya Agricultural \\ Research Institute, KARI-Kakamega, Kakamega, Kenya. \\ Email: *enjohn75@yahoo.co.uk
}

Received November $4^{\text {th }}$, 2011; revised January $10^{\text {th }}$, 2012; accepted February $20^{\text {th }}, 2012$

\begin{abstract}
Cassava (Manihot esculenta Cranzt) is an important food security crop for poor rural communities particularly in Africa. However, little is known about variability of critical root nutritional and quality traits of African cassava germplasm. Cassava roots contain low levels of important micronutrients and its quality can be influenced by the levels of cyanogenic glucosides. Roots from fourteen accessions comprising Kenyan local landraces and improved clones were screened for their nutritional traits including the contents of cyanogenic glycosides, protein and the micro nutrients iron and zinc. Trait stability and the effects of the environment on the expression of the nutritional traits were evaluated using various genotype $(G)$ by environment $(E)$ interaction study models. There were significant $(p \leq 0.05)$ differences for all the nutritional traits in the three test sites of Baringo, Kericho and Nakuru in Kenya. Contents of cyanogenic glycosides in both roots and leaves, total root proteins, root iron and zinc ranged from $31.8 \mathrm{ppm}$ to $90.8 \mathrm{ppm} ; 20.8 \mathrm{ppm}$ to $154.4 \mathrm{ppm} ; 1.15 \%$ to $3.47 \%$; $17.81 \mathrm{ppm}$ to $59.69 \mathrm{ppm}$ and $39.39 \mathrm{ppm}$ to $118 \mathrm{ppm}$, respectively. The sites were also significantly $(p \leq 0.05)$ different from each other with the highest cyanogenic content in leaves and roots expressed at the Nakuru site. Regression analysis was used to assess genotype response to environments. Regression coefficients $\left(b_{i}\right)$ obtained ranged from 0.13 to 2.23 for all traits combined indicating wide variability in quality trait among the test germplasm. Analysis for sensitivity to environmental change $\left(S E_{i}^{2}\right)$ revealed that cassava genotypes differed in their level of sensitivity. The root cyanide trait had the highest mean $\left(S E_{i}^{2}\right)$ which indicated that it was the least stable quality trait in the cassava germplasm. This implies that the same cassava genotypes will give food of different quality depending on growing environment. The observed values for protein and mineral contents suggest the potential for improving the nutritive value of local cassava germplasm.
\end{abstract}

Keywords: Cassava; Quality; Cyanogenic Glycosides; Protein; Iron; Zinc

\section{Introduction}

Cassava (Manihot esculenta Cranzt) is a perennial crop native to tropical America [1,2]. About 70 million people obtain more than 500 cal per day from the crop [3,4]. The crop offers the advantage of a flexible harvesting time, allowing farmers to keep the roots in the ground until needed [5]. In addition, the crop produces reasonably well under growth limiting conditions. In Africa, it is recognized as a famine reserve crop due to its tolerance to drought or infertile soils, and its ability to recover from disease and pest attacks. The area of cassava under unfavorable environments has been continuously increasing [6]. The crops starchy root is widely used world

*Corresponding author. wide, though the fresh foliage is also consumed in several regions of the world. A limiting characteristic for the human or animal consumption of cassava roots is their cyanogenic glycosides content [7].

All cassava tissues, with the exception of seeds, contain the cyanogenic glycosides linamarin ( $>90 \%$ total cyanogens) and lotaustralin ( $<10 \%$ total cyanogens). Cyanogenesis is initiated in cassava when the plant tissue is damaged. Rupture of the vacuole releases linamarin, which is hydrolyzed by linamarase, a cell wall-associated $\beta$-glycosidase [8]. Because of the presence of cyanoglycosides, cassava is potentially toxic to human populations that subsist on cassava-based diets and low ingestion of protein. Considerable medical evidence exists to associate consumption of high cyanide cassava with toxic 
effects in humans [9]. Typical signs of acute cyanide poisoning include tachypnoea, headache, vertigo, lack of motor coordination, weak pulse, cardiac arrhythmias, vomiting, stupor, convulsions, and coma [10-12]. Tropical ataxic neuropathy, an upper motor neuron disease characterized by irreversible paraparesis [13], was described in Nigeria in the 1930s, and dietary cassava was proposed to be the causative factor. When consumers associate ill health with cassava toxicity, the immediate reaction is to discard or substitute cassava with other food crops and this problem has lead to cassava being rejected in some areas. This is despite the fact that the cyanogens are removed by the traditional processing methods which include grating, fermenting, boiling and drying.

Cassava varieties vary widely in their cyanogenic glycoside content, although most varieties contain 15 - 400 $\mathrm{mg}$ cyanide/kg fresh weight. Occasionally tubers of some varieties of cassava tubers contain 1300 - 2000 mg cyanide/kg fresh weight, and cassava leaves may contain 1000 - 2000 mg cyanogenic glycosides/kg on a dry matter basis [14]. The cyanide yielding capacity of cassava roots is not only dependent on the genetic character of the genotype grown, but also on several environmental and growth factors [15]. Consequently, movement of a genotype from one location to another could alter its cyanogenic potential because of differences in climate and soil characteristics $[16,17]$. It was however noted that different genotypes of cassava do not react the same way with the changing environmental conditions with regard to cyanogenic glycosides [18]. This results in considerable variation of toxicity between the same varieties grown under different conditions. Despite this plasticity, characterization of cyanide yielding capacity of several genotypes in one experiment is useful to match genotypes to environment with respect to this important quality trait.

Like all food sources, cassava is also meant to provide vital nutrients to its consumers. Cassava however has the potential of being a dysfunctional food owing to its low nutrient content. Today, over three billion people are afflicted with micronutrient malnutrition and the numbers are increasing [19-21]. Nearly two-thirds of all deaths of children are associated with nutritional deficiencies that mainly arise from micronutrients deficiencies [22]. Marginal intakes of micronutrients have been shown to contribute to increased morbidity and mortality rates, diminished livelihoods, and adverse effects on learning ability, development, and growth in infants and children [21,22]. Much of the observed stunted childhood growth has been attributed to the impact of micronutrient deficiencies from early foetal stages of development through the fourth year of life. By any measure, micronutrient malnutrition is currently of alarming proportions in many developing nations $[19,23]$. Cassava roots are particularly low in protein and some micronutrients are valued only as a source of energy in human and animal diets [24,25]. Since the roots are grossly deficient in proteins, fat, some minerals for example zinc and iron and vitamins [26], continued consumption can lead to malnutrition.

Developing low cyanogen and micronutrient-enriched cassava, either through traditional plant breeding methods or via biotechnology, is a powerful intervention tool that can enhance the health status of many resource-poor consumers in Africa [27,28]. Biofortifying cassava that feeds the world's poor can significantly improve the amount of these nutrients consumed by these target populations [29]. This is a sustainable intervention, unlike traditional interventions that are dependent on supplementation and fortification programmes [30,31].

Even as efforts are made to identify and develop healthy and nutritious biofortified cassava cultivars, the quality traits of such cultivars must be stable across environments. Local landraces of cassava have been cultivated widely in traditional cassava areas in Kenya. These landraces have however hardly been tested outside their traditional environments for biochemical quality traits. Similarly, they have not been compared for stability of their biochemical quality traits relative to newly introduced and improved accessions. The stability of cassava quality traits over a wide range of environments would be generally regarded desirable as the resulting products would be uniform in quality under different growing environments. Stability measures used to characterize genotype (G) by environment (E) interactions among cultivars at various stages of germplasm development employ different models that measure response to environmental changes and the consistence of that response (stability) [32]. The most widely used approach has been based on linear regression of cultivar traits on an environmental index $\left(b_{i}\right)$ derived from the average performance of all cultivars in a site [33-37]. The conventional analysis of variance has also been widely used to detect $\mathrm{G}$ by $\mathrm{E}$ interactions [38]. The variance of a genotype across environments, which is also a measure of sensitivity to environmental changes $\left(S E_{i}^{2}\right)$, has also been used as a stability measure [37].

The objective of this study was to determine for the first time the relative performance, adaptation and stability of quality traits in selected cassava germplasm including some local land races and improved accessions which were introduced to the central Rift valley of Kenya for the first time.

\section{Materials and Methods}

Fourteen cassava accessions (Table 1), which included local Kenyan land races and some improved lines from International Institute of Tropical Agriculture (IITA) and Centre Internacional de Agricultural Tropical (CIAT) were used in this study. 
Table 1. Cassava germplasm (accessions).

\begin{tabular}{cc}
\hline Accessions & Accessions \\
\hline Migyera $^{*}$ & MM96/3868 $^{+}$ \\
SS4 $^{\dagger}$ & MM96/1871 $^{\dagger}$ \\
Mucericeri $^{*}$ & MH95/0183 $^{\dagger}$ \\
KME-1 $^{\dagger}$ & Serere $^{*}$ \\
MM96/4466 $^{\dagger}$ & $990067^{\dagger}$ \\
MM96/7151 $^{\dagger}$ & $990072^{\dagger}$ \\
MM96/4884 $^{\dagger}$ & KME-61 $^{\dagger}$ \\
\hline
\end{tabular}

* Local landraces; ${ }^{\dagger}$ Improved cultivars from CIAT and IITA.

The accessions were planted for the first time at three sites in Central Rift valley of Kenya; Kericho (Soin), Nakuru (Subukia), and Baringo (Marigat) districts of central Rift Valley in Kenya (Table 2). The cassava germplasm were selected because of their high yields, disease resistance and popularity. The accessions were planted in a randomized complete block design (RCBD) with three replications. The plot sizes were $3 \mathrm{M} \times 4 \mathrm{M}$ while the plant spacing was $1 \mathrm{M} \times 1 \mathrm{M}$ giving twelve plants per plot. Cassava cuttings measuring $15 \mathrm{~cm}$ long from each variety were planted in five rows. No fertilizers or herbicides were applied during the course of the experiment. For Nakuru and Kericho sites, the trials were rain fed while at Baringo, the trial was under irrigation which was done twice in a week. Destructive sampling of the plants was done at 13th month after planting.

Cyanide levels were determined in leaves and roots using a modified picrate testing procedure [39]. The samples were rated for cyanide levels on a scale of 1 - 9 . The score structure ranged from scale of 1 - 4 representing 0 - 50 ppm, 5 - 6 representing 50 - 100 ppm and 7 - 9 representing over $100 \mathrm{ppm}$. The cassava accessions were ranked as low, medium and high cyanide content respectively.

Crude protein content was determined on root samples using the method of Association of American Cereal Chemists [40]. The CF used was 6.25 specific for cassava plant sample. The whole process was replicated three times with a control consisting of all the reagents and conditions used except the experimental samples.

The two micronutrients, iron and zinc were determined as follows. Three plants per variety were harvested at tenth month after planting. Three cassava roots of different sizes were randomly selected per variety and labeled appropriately. The roots were then washed in tap water to remove soil and dirt, and air dried on a chuxlined surface. The roots were peeled with stainless steel knife and rinsed in distilled water and sliced thinly before drying.

All samples were dried in an air oven at $60^{\circ} \mathrm{C}$ for about 72 hours, then cooled to ambient temperature, milled by means of a hammer mill and sieved through a mesh of 1
Table 2. Environmental descriptors of trial sites.

\begin{tabular}{cccc}
\hline Trial site & Alt. masl & Soil type & Annual rainfal \\
\hline Baringo (Marigat) & 1066 & Fluvisols & $590(\mathrm{~mm})$ \\
Kericho (Soin) & 1315 & Nitisols & $1356(\mathrm{~mm})$ \\
Nakuru (Subukia) & 1676 & Andosols & $800(\mathrm{~mm})$ \\
\hline
\end{tabular}

mm diameter. The milled samples were stored in airtight plastic containers until required for analysis. Sample of 0.3 grammes of finely ground and dried cassava root samples were weighed in a dry clean digestion tube. Then, $2.5 \mathrm{ml}$ of the digestion mixture (7.2 g salicylic acid in $100 \mathrm{ml}$ of the selenium-sulphuric acid mixture) was added and allowed to react at room temperature for at least 2 hours. The digestion tubes were heated to $200^{\circ} \mathrm{C}$ in a block digester (Model 2040, Foss-Denmark), allowed to cool and 3 successive portions of $1 \mathrm{ml}$ of hydrogen peroxide added, waiting at least 10 seconds between additions. The tubes were returned to the block digester and temperatures adjusted to $330^{\circ} \mathrm{C}$. The digestion was complete when the digest became colourless or light yellow. The tubes were removed from the block digester and cooled to room temperature then the contents transferred into a $50 \mathrm{ml}$ volumetric flask and made up to the mark with deionised water.The digested samples were analyzed for trace metals (iron and zinc), using the Atomic Absorption Spectrophotometer, (Model AA-6300, TokyoJapan). The instrument was calibrated using standard solutions of iron ( $\mathrm{Fe}$ in $\mathrm{HNO}_{3}$; iron standard solution 10 ppm) and zinc ( $\mathrm{Zn}$ in $\mathrm{HNO}_{2}$; zinc standard solution 10 $\mathrm{ppm}$ ) and measured by atomic absorption as they were absorbing radiations from element-specific hollow cathode lamps at a wavelength of $248.3 \mathrm{~nm}$ and $213.9 \mathrm{~nm}$, respectively. The absorbencies obtained were used to calculate the concentrations of the metals in the different samples [41].

\section{Statistical Analysis}

Analysis of Variance (ANOVA) for data for cyanide, protein, zinc and iron content was done using the SAS package. Means were separated using LSD [42]. Regression coefficients $\left(b_{i}\right)$ and sensitivity to environmental change ( $S E_{i}^{2}$ ) was computed to describe stability as described by Lin [32].

\section{Results and Discussions}

The analysis of variance (ANOVA) showed that genotypes (G) at the Baringo site were significantly different $(p \leq 0.05)$ in mean values for leaf and root cyanide, root protein and root zinc (Tables 3(a) and (b)). Accession MM96/3868 recorded the highest concentration of cyanide in leaves (71.25 ppm) which was above the safe 
Table 3. (a) Mean concentrations for leaf and root cyanide of cassava accessions tested at Baringo, Kericho and Nakuru sites of the central; (b) Mean percent for root protein and mean concentrations for iron and zinc of cassava accessions tested at Baringo, Kericho and Nakuru sites of the central Rift Valley, Kenya.

(a)

\begin{tabular}{|c|c|c|c|c|c|c|}
\hline \multirow{2}{*}{$\begin{array}{l}\text { Cassava germplasm } \\
\text { (accessions) }\end{array}$} & \multicolumn{3}{|c|}{ Leaf cyanide (ppm) } & \multicolumn{3}{|c|}{ Root cyanide (ppm) } \\
\hline & Baringo & Kericho & Nakuru & Baringo & Kericho & Nakuru \\
\hline Migyera* & 55.42abcd & $70.42 \mathrm{a}$ & 64.17cdef & $112.14 \mathrm{a}$ & $40.56 \mathrm{bc}$ & $56.67 \mathrm{ef}$ \\
\hline $\mathrm{SS}^{\dagger}$ & 47.92cde & $31.82 \mathrm{c}$ & 53.33ef & 73.33bcde & $53.13 \mathrm{bc}$ & 115.56abcd \\
\hline Mucericeri* $^{*}$ & $33.00 \mathrm{e}$ & $31.82 \mathrm{c}$ & 64.58bcde & 43.75de & 23.8 & 75.56de \\
\hline KME-1 $^{\dagger}$ & 40.00cde & $38.33 c$ & $53.75 \mathrm{ef}$ & $40.00 \mathrm{e}$ & $56.11 b c$ & 75.63de \\
\hline MM96/4466 ${ }^{\dagger}$ & 54.58abcd & $44.04 \mathrm{bc}$ & $42.92 \mathrm{f}$ & 63.33bcde & $21.67 c$ & 93.33cde \\
\hline MM96/7151 $^{\dagger}$ & 57.08abc & 50.00abc & 78.75abcd & 77.78abcd & $54.44 \mathrm{bc}$ & 139.38ab \\
\hline MM96/4884 $^{\dagger}$ & 47.50cde & $40.42 c$ & 74.17abcde & 66.11bcde & 41.67bc & $104.44 \mathrm{bcd}$ \\
\hline MM96/3868 $^{\dagger}$ & $71.25 \mathrm{a}$ & $42.92 \mathrm{bc}$ & 62.50cdef & 89.44abc & $51.67 \mathrm{bc}$ & 92.22cde \\
\hline MM96/1871 ${ }^{\dagger}$ & 51.25abcde & $50.45 \mathrm{abc}$ & 85.83ab & 76.67bcd & $55.00 \mathrm{bc}$ & 114.29abcd \\
\hline MH95/0183 ${ }^{\dagger}$ & 69.17ab & 49.13bc & 82.92abc & 54.29cde & $40.00 \mathrm{bc}$ & $154.44 a$ \\
\hline Serere $^{*}$ & 70.00ab & $70.42 a$ & $90.83 a$ & 75.00bcde & $58.33 \mathrm{bc}$ & $20.83 f$ \\
\hline $990067^{\dagger}$ & 35.42de & $40.00 \mathrm{c}$ & 58.18def & 93.13ab & $96.67 a$ & 78.00de \\
\hline $990072^{\dagger}$ & 49.58bcde & 49.58bc & 78.33abcd & 88.33abc & 66.11ab & 132.50abc \\
\hline KME-61 ${ }^{\dagger}$ & 55.00abcd & $62.00 \mathrm{ab}$ & 82.50abc & 77.50abcd & 63.57ab & 82.22de \\
\hline Site Mean & 52.94 & 45.17 & 69.55 & 74.64 & 51.79 & 98.28 \\
\hline $\operatorname{LSD}(p=0.05)$ & 0.003 & 0.03 & 0.0001 & 0.03 & 0.05 & 0.0001 \\
\hline
\end{tabular}

*Local landraces; ${ }^{\dagger}$ Improved cultivars from CIAT and IITA.

(b)

\begin{tabular}{|c|c|c|c|c|c|c|c|c|c|}
\hline \multirow{2}{*}{$\begin{array}{l}\text { Cassava germplasm } \\
\text { (accessions) }\end{array}$} & \multicolumn{3}{|c|}{ Root protein (\%) } & \multicolumn{3}{|c|}{ Root iron (ppm) } & \multicolumn{3}{|c|}{ Root zinc (ppm) } \\
\hline & Baringo & Kericho & Nakuru & Baringo & Kericho & Nakuru & Baringo & Kericho & Nakuru \\
\hline Migyera $^{*}$ & $2.13 c d$ & 1.27 & 2.05 & 25.59 & $36.80 \mathrm{~cd}$ & 25.85 & $104.76 \mathrm{ab}$ & $64.56 f$ & $59.51 \mathrm{bcd}$ \\
\hline $\mathrm{SS}^{\dagger}$ & $2.56 \mathrm{bc}$ & 1.49 & 2.56 & 23.56 & 29.89d & 22.49 & $49.67 \mathrm{~d}$ & $80.21 b c d$ & 86.12abc \\
\hline Mucericeri* & . & 1.45 & 3.43 & 27.8 & $42.06 \mathrm{c}$ & 17.81 & 69.63cd & 86.23abc & 91.88ab \\
\hline KME-1 $^{\dagger}$ & $1.96 \mathrm{cde}$ & 1.52 & 2.85 & 26.75 & 37.10cd & 34.17 & 58.50cd & $93.07 a$ & 87.75ab \\
\hline MM96/4466 $^{\dagger}$ & $1.25 \mathrm{e}$ & 1.4 & 3.19 & 34.18 & 37.93cd & 19.72 & 87.14abc & 84.19abcd & $54.46 \mathrm{~cd}$ \\
\hline MM96/7151 $^{\dagger}$ & 3.01ab & 1.38 & 3.09 & 23.28 & 39.53cd & 26.44 & $44.87 d$ & 78.47bcde & $46.78 d$ \\
\hline MM96/4884 & $1.27 \mathrm{e}$ & 1.15 & 3.08 & 28.55 & $41.19 \mathrm{c}$ & 22.49 & 58.76cd & 74.13cdef & $69.23 \mathrm{bcd}$ \\
\hline MM96/3868 $^{\dagger}$ & 1.62ed & 1.54 & 2.29 & 29.24 & 43.33bc & 23.85 & $62.58 \mathrm{~cd}$ & 72.04edf & 82.71abcd \\
\hline MM96/1871 $^{\dagger}$ & $1.57 \mathrm{ed}$ & 1.38 & 2.98 & 30.39 & $46.15 b c$ & 26.19 & $48.50 \mathrm{~d}$ & 76.48bcdef & 69.67bcd \\
\hline Мн95/0183 ${ }^{\dagger}$ & $3.47 \mathrm{a}$ & 1.41 & 2.58 & 37.51 & $41.09 \mathrm{c}$ & 23.76 & $110.76 a$ & 80.32abcd & $75.32 \mathrm{bcd}$ \\
\hline Serere $^{*}$ & $1.29 \mathrm{e}$ & 1.57 & 2.66 & 26.05 & $40.99 c$ & 27.16 & 39.39d & 89.13ab & 95.81ab \\
\hline $990067^{\dagger}$ & 1.98cde & 1.49 & 3.02 & 34.37 & $44.59 \mathrm{bc}$ & 30.48 & 62.83cd & $67.04 \mathrm{edf}$ & 86.38abc \\
\hline $990072^{\dagger}$ & 1.98cde & 1.43 & 2.72 & 31.69 & $52.97 \mathrm{ab}$ & 27.85 & 71.74bcd & 75.70cdef & 82.20abcd \\
\hline KME-61 $^{\dagger}$ & $1.35 \mathrm{e}$ & 1.4 & 2.53 & . & 59.69a & 24.44 & . & 72.93def & $118.10 \mathrm{a}$ \\
\hline Site Mean & 1.97 & 1.42 & 2.78 & 29.22 & 42.38 & 25.23 & 67.82 & 78.17 & 79.69 \\
\hline $\operatorname{LSD}(p=0.05)$ & 0.0001 & $\mathrm{n} / \mathrm{s}$ & $\mathrm{n} / \mathrm{s}$ & $\mathrm{n} / \mathrm{s}$ & 0.001 & $\mathrm{n} / \mathrm{s}$ & 0.002 & 0.004 & 0.05 \\
\hline
\end{tabular}

"Local landraces; ${ }^{\dagger}$ Improved cultivars from CIAT and IITA. 
limit of $40 \mathrm{ppm}$ while the local land race Mucericeri had the lowest concentration of cyanide (33 ppm) which is considered safe for human consumption without being processed. For cyanide in roots, cultivar Migyera had the highest concentration of cyanide (112.14 ppm) which is highly poisonous if consumed raw. Accession KME 1 had the lowest and safest levels of cyanide in roots at 40 ppm and therefore together with Mucericeri seemed to be the best overall at below $40 \mathrm{ppm}$ at this site in both cyanide in leaves and roots.

Protein values in roots at this site were above 2 percent only for the local land race Migyera and accessions SS4, MM96/7151 and MH95/0183 of which MH95/0183 had the highest level at 3.47 percent. There were no significant differences $(p \geq 0.05)$ in the levels of iron in the roots although all accessions had levels that were above 20 ppm. For zinc concentration, accession MH95/0183 had the highest level at 110.76 ppm while the local land race

Serere had a low level of $39.39 \mathrm{ppm}$. It is notable that all the test germplasm in the three test sites gave higher or equal values for iron and zinc but not less than values observed by Chavez et al., [43] for cassava collections from Meso America and Dixon et al., [44] for collections from Nigeria.

At the Kericho site, significant differences $(p \leq 0.05)$ were observed in mean leaf and root cyanide as well as root iron and zinc contents as shown in Tables 3(a) and (b). The landraces Migyera and Serere recorded the highest leaf cyanide values (70.42 ppm) while Mucericeri and SS4 recorded the lowest (31.82 ppm). Root cyanide was highest in accession 990067 (96.67 ppm) which was way above the safe critical level of consumption of $40 \mathrm{ppm}$. The lowest level of root cyanide was recorded in accession MM96/4466 (21.67 ppm). For both cyanide quality traits, the other accessions were either above or below the critical level of consumption as shown in Table 3(a). The local land race Mucericeri seemed to be the safest variety for consumption at this site for both leaves and roots as it had the lowest levels of cyanide content. Protein values in the roots at this site were not significantly ( $p \geq 0.05$ ) different from each other and were all below the 2 percent thresh hold value.

The iron concentration was highest in accession KME 61 (59.69 ppm) and lowest in accession SS4 (29.89 ppm). The zinc levels were high in KME 1 (93.07 ppm) and lowest in the local land race Migyera (64.56 ppm) although all the varieties at this site faired quite well as they were all above $64 \mathrm{ppm}$ in zinc content. An important aspect in enhancing micronutrient levels in cassava roots is ensuring a good agronomic background of micro nutrient-enriched genotypes [44].

There were also significant differences $(p \leq 0.05)$ among the germplasm at the Nakuru site in mean leaf and root cyanide and root zinc content Tables 3(a) and (b). Serere had the highest levels of cyanide in leaves (90.83 ppm). It is note worthy that the local land race Serere had in average the highest levels of cyanide in its leaves at the three sites (Table 2). Accession MH95/0183 had the highest root cyanide concentration (154.44 ppm) and therefore can be highly poisonous when consumed fresh. At this site, only Serere had cyanide root levels below the $40 \mathrm{ppm}$ threshold (20 ppm) which is the safe level for human and animal consumption. Variations similar to those observed in this study in HCN for both leaves and roots have also been reported in a study of cassava cultivars used for consumption in the Sao Paulo state of Brazil [45]. Our study revealed no significant differences ( $p$ $\geq 0.05$ ) among the varieties for root protein content at the Nakuru test site although all accessions recorded values that were over 2\% with Mucericeri, MM96/4466, MM96/7151, MM96/4884 and 990067 all having three percent and above. These high levels of root protein content $(\geq 3 \%$ ) have also been reported in some land races and improved accessions of cassava by Chavez et al., [43]. There were no significant $(p \geq 0.05)$ differences among the test accessions for root iron content at the Nakuru site. Significant ( $p \geq 0.05$ ) differences were however observed for zinc in roots with KME 61 having highest concentration (118.10 ppm) and MM96/7151 the lowest (46.78 ppm).

The three test sites (S) expressed significant $(p \leq 0.05)$ differences and overall, the site means for leaf and root cyanide, root protein and root zinc contents were all higher at the Nakuru test site when compared to the other two sites whereas mean root iron content was higher in Kericho when compared to the other two sites Tables 3(a) and (b). The soils of Kericho test site are nitisols which are rich in iron. This seems to suggest that an environment suitable for the expression of high protein and zinc content may also elicit expression of high levels of leaf and root cyanide content. This calls for judicious selection of germplasm for such a site to ensure that positive quality traits are maintained and negative traits such as high cyanide levels are selected against. The local variety Serere could be recommended for this site.

Pooled data for the combined sites revealed that levels of cyanide concentration in leaves and roots were signifi cantly ( $p \leq 0.05$ ) different from each other (Table 4 ), although all the values were above the accepted critical level of $40 \mathrm{ppm}$. However, the local landrace Mucericeri seemed to have faired well for both the traits with the lowest average cyanide concentration in ppm. This therefore indicates that proper processing needs to be applied for all cassava cultivated in the Central Rift valley of Kenya before human consumption. In the roots, which is the most consumed part of cassava plant, accession 990072 had the highest levels of cyanide (94.23 ppm) 
Table 4. Combined sites data for quality traits (cyanide in leaves and roots, protein in roots, iron and zinc in roots) in fourteen cassava accessions tested at Baringo, Kericho and Nakuru sites of central Rift Valley, Kenya.

\begin{tabular}{|c|c|c|c|c|c|}
\hline $\begin{array}{l}\text { Cassava germplasm } \\
\text { (accessions) }\end{array}$ & $\begin{array}{l}\text { Leaf cyanide } \\
\quad(\mathrm{ppm})\end{array}$ & $\begin{array}{l}\text { Root cyanide } \\
(\mathrm{ppm})\end{array}$ & $\begin{array}{l}\text { Root protein } \\
(\%)\end{array}$ & $\begin{array}{l}\text { Root iron } \\
\text { (ppm) }\end{array}$ & $\begin{array}{l}\text { Root zinc } \\
(\mathrm{ppm})\end{array}$ \\
\hline Migyera* & 50.86def & 67.73cdef & 1.77 & 29.86 & 78.37 \\
\hline $\mathrm{SS}_{4}^{\dagger}$ & $44.71 \mathrm{f}$ & 81.73abc & 2.18 & 25.53 & 74.79 \\
\hline Mucericeri $^{*}$ & $44.09 \mathrm{f}$ & $50.68 \mathrm{f}$ & 2.35 & 29.23 & 82.58 \\
\hline KME-1 ${ }^{*}$ & $44.14 \mathrm{f}$ & 57.20def & 2.10 & 33.41 & 82.43 \\
\hline MM96/4466 ${ }^{\dagger}$ & 47.18ef & $55.21 \mathrm{ef}$ & 1.79 & 31.99 & 77.86 \\
\hline MM96/7151 ${ }^{\dagger}$ & 61.94bcd & 88.65abc & 2.50 & 30.16 & 56.71 \\
\hline MM96/4884 ${ }^{\dagger}$ & 54.03cdef & 70.74bcdef & 1.83 & 30.74 & 67.37 \\
\hline MM96/3868 ${ }^{\dagger}$ & 58.89bcde & 77.78abcd & 1.81 & 32.50 & 73.68 \\
\hline MM96/1871 ${ }^{\dagger}$ & $62.86 \mathrm{bc}$ & 79.40abc & 1.92 & 34.24 & 64.88 \\
\hline MH95/0183 & 67.07ab & 85.20abc & 2.49 & 34.12 & 88.80 \\
\hline Serere $^{*}$ & $77.08 \mathrm{a}$ & 55.21ef & 1.74 & 31.93 & 72.15 \\
\hline $990067^{\dagger}$ & $44.14 \mathrm{f}$ & $91.14 \mathrm{ab}$ & 1.92 & 36.74 & 73.24 \\
\hline $990072^{\dagger}$ & 59.17bcd & $94.23 a$ & 2.00 & 37.50 & 76.55 \\
\hline KME- $61^{\dagger}$ & $67.50 \mathrm{ab}$ & 75.00abcde & 1.88 & 42.07 & 95.52 \\
\hline Site mean & 56.02 & 73.89 & 2.02 & 32.71 & 75.56 \\
\hline $\operatorname{LSD}(p=0.05)$ & 0.0001 & 0.0005 & $\mathrm{n} / \mathrm{s}$ & $\mathrm{n} / \mathrm{s}$ & $\mathrm{n} / \mathrm{s}$ \\
\hline
\end{tabular}

*Local landraces; ${ }^{\dagger}$ Improved cultivars from CIAT and IITA.

while Mucericeri recorded the lowest (50.68 ppm) (Table 4).

The significance of sites (S) by genotypes (G) effects demonstrates that genotypes responded differently to variations in environmental conditions. These variations could be attributed to different climatic and edaphic conditions at sites (S) (Table 2). The significant $(p \leq 0.05)$ interacttion of sites and genotypes ( $\mathrm{S}$ by $\mathrm{G}$ ) indicated the necessity of testing cassava accessions at multiple locations over time for accurate characterization of genotype performance over divergent geographical regions.

Except for root iron content, the Nakuru site elicited the expression of high levels of cyanide, protein and zinc in the tested cassava accessions. Like the other test sites, this is a non cassava traditional growing site. Low root cyanogenic genotypes like Serere (20 ppm), Migyera (56.67 ppm), Mucericeri (75.56 ppm) and KME 1 (75.63 $\mathrm{ppm}$ ) are recommended for this site. Choice of high cyanogenic content genotypes in Nakuru site could result in HCN poisoning of consumers and therefore processing is recommended before consumption. At the Kericho site, all the cultivars except 990067 (96.67 ppm) were relatively safe. At Baringo site, except for accessions Migyera (112.14) and 990067 (93.13 ppm), some were relative safe for consumption while on others, simple processing methods like soaking and boiling could be applied.

Farmers preferred cultivars faired well in root cyanide with Mucericeri having lowest level of 50.68 ppm as compared to improved accessions (Table 4). For root protein, farmers preferred cultivars SS4, Mucericeri and KME 1 had levels of over $2 \%$ although some improved accessions like MM96/7151, MH95/0183 and 990072 had also acceptable levels of over $2 \%$. In root iron and zinc, there was acceptable performances for both farmer preferred and improved cultivars with KME 61 having highest levels for both quality traits at $32.71 \%$ and $75.56 \%$ for iron and zinc respectively.

The regression of mean accession trait values on environmental index resulted in significantly $(p \leq 0.05)$ heterogeneous regressions, with regression coefficients $\left(b_{i}\right)$ ranging from 0.36 to 1.44 for leaf cyanide; 0.13 to 2.30 for root cyanide; 0.31 to 1.58 for root protein; 0.49 to 2.23 for root iron and 0.15 to 1.05 for root zinc (Table 5). The significant heterogeneity of regressions was also an indication of effective $\mathrm{G}$ by $\mathrm{E}$ interactions. Large variations in $b_{i}$ indicate large differences in genotype responses to different environments. Regression values above 1.0 describe genotypes with higher sensitivity to environmental change (below average stability) and greater specificity of adaptability to high trait value environments. Regression coefficients decreasing below 1.0 provide a measure of greater resistance to environmental change (above average stability), and therefore increasing specificity of adaptability to low trait value environments. Accessions MM96/3868 for root protein and SS4 and 990067 for root iron had larger $b_{i}$ values indicating greater sensitivity to environmental change. 
Table 5. Measure of stability regression coefficient $\left(b_{i}\right)$ and sensitivity to environmental changes ( $\left.S E_{i}^{2}\right)$ for five quality traits in fourteen cassava accessions tested at three sites in the central Rift Valley of Kenya.

\begin{tabular}{|c|c|c|c|c|c|c|c|c|c|c|}
\hline \multirow{2}{*}{$\begin{array}{l}\text { Cassava germplasm } \\
\text { (accessions) }\end{array}$} & \multicolumn{2}{|c|}{$\begin{array}{l}\text { Leaf cyanide } \\
\text { (ppm) }\end{array}$} & \multicolumn{2}{|c|}{$\begin{array}{l}\text { Root cyanide } \\
\text { (ppm) }\end{array}$} & \multicolumn{2}{|c|}{$\begin{array}{l}\text { Root protein } \\
\text { (\%) }\end{array}$} & \multicolumn{2}{|c|}{$\begin{array}{l}\text { Root iron } \\
\text { (ppm) }\end{array}$} & \multicolumn{2}{|c|}{$\begin{array}{l}\text { Root zinc } \\
\text { (ppm) }\end{array}$} \\
\hline & $b i$ & $S E_{i}^{2}$ & $b i$ & $S E_{i}^{2}$ & $B i$ & $S E_{i}^{2}$ & $b i$ & $S E_{i}^{2}$ & $b i$ & $S E_{i}^{2}$ \\
\hline Migyera* & -0.36 & 56.76 & 0.12 & 1410.02 & 1.08 & 0.22 & 1.36 & 40.93 & -0.26 & 614.84 \\
\hline $\mathrm{SS}^{\dagger}$ & 0.98 & 124.81 & 0.71 & 1014.81 & 0.89 & 0.37 & 2.23 & 15.99 & 0.32 & 382.69 \\
\hline Mucericeri $^{*}$ & 1.43 & 343.17 & 0.88 & 679.49 & 0.68 & 0.98 & 0.72 & 148.25 & 0.55 & 133.75 \\
\hline $\mathrm{KME}-1^{\dagger}$ & -0.56 & 71.6 & 0.72 & 318.34 & 1.00 & 0.46 & 0.91 & 28.45 & 0.33 & 346.49 \\
\hline MM96/4466 ${ }^{\dagger}$ & -0.56 & 31.46 & 0.64 & 1295.11 & 0.56 & 1.16 & 0.75 & 92.45 & -0.23 & 326.75 \\
\hline MM96/7151 ${ }^{\dagger}$ & 0.82 & 224.37 & 0.51 & 1925.68 & 0.58 & 0.93 & 0.95 & 74.22 & 0.15 & 356.13 \\
\hline MM96/4884 ${ }^{\dagger}$ & 0.69 & 316.74 & 0.72 & 1001.09 & 0.59 & 1.16 & 0.93 & 91.02 & 0.74 & 61.63 \\
\hline MM96/3868 ${ }^{\dagger}$ & 0.43 & 210.41 & 0.91 & 513.09 & 1.57 & 0.16 & 0.89 & 101.17 & 0.58 & 101.42 \\
\hline MM96/1871 ${ }^{\dagger}$ & 0.58 & 408.02 & 0.76 & 900.02 & 0.74 & 0.76 & 0.85 & 110.73 & 0.41 & 212.9 \\
\hline MH95/0183v & 0.69 & 318.73 & 0.34 & 3888.45 & 0.31 & 1.06 & 0.79 & 83.69 & -0.33 & 367.93 \\
\hline Serere* & 0.98 & 140.26 & -0.57 & 769.75 & 0.77 & 0.52 & 1.03 & 69.27 & 0.20 & 950.31 \\
\hline $990067^{\dagger}$ & 0.90 & 144.91 & -2.21 & 99.83 & 0.87 & 0.60 & 1.23 & 53.11 & 0.37 & 157.72 \\
\hline $990072^{\dagger}$ & 0.71 & 275.03 & 0.67 & 1142.05 & 1.05 & 2.21 & 0.66 & 183.09 & 1.04 & 27.88 \\
\hline KME- $61^{\dagger}$ & 0.73 & 204.25 & 2.29 & 94.01 & 0.92 & 0.43 & 0.48 & 310.63 & 0.03 & 510.07 \\
\hline
\end{tabular}

${ }^{*}$ Local landraces; ${ }^{\dagger}$ Improved cultivars from CIAT and IITA.

These accessions had relatively large quality trait values in environments that favored such large trait values but also expressed low trait values in low trait value environments when compared to the other genotypes. The inability of these genotypes to maintain their quality traits values under poor growing conditions may presumably be because of their lesser ability to tolerate stresses relative to others. All the other genotypes with low $b_{i}$ values indicated their resistances to environmental changes were more adapted to low trait value environments. For the negative traits of root and leaf cyanide contents, cultivars Mucericeri and KME 61 had large $b_{i}$ values, respectively. These accessions exhibited great trait sensitivity to environmental change and therefore were unstable with regard to expression of the cyanogenic glycosides. Accession 990067 had a regression coefficient of -2.2 for root cyanide content and cyanogenic glycosides decreased in this accession as the environmental index increased.

Accessions which had the smallest environmental variance $\left(S E_{i}^{2}\right)$ were; accessions MM96/4466 for leaf cyanide, KME 61for root cyanide, MM96/3868 for root protein, SS4 for root iron and 990072 for root zinc (Table 5). Additionally, the following accessions had the largest $S E_{i}^{2}$; MM96/1871 for leaf cyanide, MH95/0183 for root cyanide, 990072 for root protein, KME 61 for root iron and Serere for root zinc. This is an indication that these genotypes are most sensitive to changes in the environment and therefore are unstable. The parametric approaches used in our study did not however seem to pro- vide an overall picture of the individual genotype responses to the environment. Some genotypes exhibited stability for one type of measure and instability to the other. This is a problem that has been identified in G by E interaction studies [32].

Correlation coefficients between cassava quality traits were not significantly $(p \geq 0.05)$ different (Table 6). All the traits were positively correlated except for leaf cyanide versus root protein; root cyanide versus root zinc and root protein versus root iron. This may indicate that the biochemical quality traits are not linked and it is therefore possible to enhance one trait without adversely affecting the other.

\section{Conclusions}

There is great variation in the different cassava quality parameters studied which can be attributed to the different accessions and growing environments. The observed values for protein and mineral contents suggest the potential for improving the nutritive value of cassava in Kenya.

However, the variation observed in cyanide concentrations calls for rational choice of low cyanogenic cultivars for release in these non-cassava traditional areas. More caution is needed when handling cassava germplasm in Nakuru district because of the very high levels of hydrogen cyanide recorded in this site.

There are also ample compelling national human health 
Table 6: Phenotypic correlation coefficient for cassava quality traits (leaf cyanide, root cyanide, root protein, root iron and zinc) across the three test sites.

\begin{tabular}{lccccc}
\hline & $\begin{array}{c}\text { Leaf } \\
\text { cyanide }\end{array}$ & $\begin{array}{c}\text { Root } \\
\text { cyanide }\end{array}$ & $\begin{array}{c}\text { Root } \\
\text { protein }\end{array}$ & Root iron & Root zinc \\
\cline { 2 - 6 } Leaf cyanide & 1.00 & 0.137 & -0.001 & 0.334 & -0.003 \\
$\begin{array}{c}\text { Root } \\
\text { cyanide }\end{array}$ & & 1.000 & 0.269 & 0.277 & -0.248 \\
Root protein & & 1.000 & -0.233 & 0.002 \\
Root iron & & & 1.000 & 0.440 \\
Root zinc & & & & & 1.000 \\
\hline
\end{tabular}

and nutritional reasons to encourage plant breeders to pursue improving the micronutrient content of cassava crop as a primary objective in their work. Succeeding in doing this would dramatically contribute to improving the health, livelihood and felicity of numerous resourcepoor, micronutrient-deficient people in Kenya and would contribute greatly to sustaining national development efforts.

\section{Acknowledgements}

The authors wish to express their gratitude to the Rockefeller Foundation and International Atomic Energy Agency for financial support through the grants. We acknowledge the assistance of researchers and technicians of Kenya Agricultural Research Institute-Njoro and for their participation in the study.

\section{REFERENCES}

[1] C. A. Allen, "The Origin of Manihot esculenta Crantz (Euphorbiaceae)," Crop Evolution, Vol. 41, No. 3, 1994, pp. 133-150. doi:10.1007/BF00051630

[2] K. M. Olsen and B. A. Schaal, "Microsatellite Variation in Cassava (Manihot esculenta, Euphorbiaceae) and Its Wild Relatives: Further Evidence for a Southern Amazonian Origin of Domestication," American Journal of Botany, Vol. 88, No. 1, 2001, pp. 131-142. doi: $10.2307 / 2657133$

[3] J. Cock, "Cassava. New Potential for a Neglected Crop," Westview Press, Boulder, 1985.

[4] K. Kawano, K. Narintaraporn, P. Narintaraporn, S. Sarakarn, A. Limsila and W. Watananonta, "Yield Improvement in a Multistage Breeding Program for Cassava," Crop Science, Vol. 38, No. 2, 1998, pp. 325-332. doi:10.2135/cropsci1998.0011183X003800020007x

[5] C. Iglesias, J. Mayer, A. L. Ch'avez and F. Calle, "Genetic Potential and Stability of Carotene Content in Cassava Roots,” Euphytica, Vol. 94, No. 3, 1997, pp. 367-373. doi:10.1023/A:1002962108315

[6] M. A. El-Sharkawy, "Drought-Tolerant Cassava for Africa, Asia and Latin America,” Biological Science, Vol. 43, 1993, pp. 441-451.

[7] P. Kakes, "Properties and Functions of the Cyanogenic
System in Higher Plants,” Euphytica, Vol. 48, No. 1, 1990, pp. 25-43.

[8] J. M. M. Mahon, W. L. B. White and R. T. Sayre, "Cyanogenesis in Cassava (Manihot esculenta Crantz)," Journal of Experimental Botany, Vol. 46, No. 288, 1995, pp. 731-741.

[9] P. Lundquist, "Determination of Cyanide and Thiocyanate in Humans,” Linkoping University, Linkoping, 1992, p. 142.

[10] B. Ballantyne, "Acute Systemic Toxicity of Cyanides by Topical Application to the Eye," Journal of Toxicology, Vol. 2, No. 2-3, 1983, pp. 119-129.

[11] J. L. Way, "Cyanide Intoxication and Its Mechanism of Antagonism," Annual Review of Pharmacology and Toxicology, Vol. 24, 1984, pp. 451-481. doi:10.1146/annurev.pa.24.040184.002315

[12] R. P. Johnson and J. W. Mellors, “Arteriolization of Venous Blood Gases: A Clue to the Diagnosis of Cyanide Poisoning," Journal of Emergency Medicine, Vol. 6, No. 5, 1988, pp. 401-404. doi:10.1016/0736-4679(88)90014-5

[13] M. Ernesto, A. P. Cardoso, D. Nicala, E. Mirione, F. Massaza, J. Cliff, M. R. Haque and J. H. Bradbury, "Persistent Konzo and Cyanogens Toxicity from Cassava in Northern Mozambique," Acta Tropica, Vol. 82, No. 3, 2002, pp. 357-362. doi:10.1016/S0001-706X(02)00042-6

[14] G. Padjmaja, "Cyanide Detoxification in Cassava for Food and Feed Use," Critical Reviews in Food Sciences and Nutrition, Vol. 35, 1995, pp. 259-339.

[15] H. Rosling, “Cassava Toxicity and Food Security,” Report for UNICEF African Household Food Security Programme, 1988, p. 40.

[16] M. R. Grace, “Elaboracion de la Yuca,” Coleccion FAO: Organization de las, 1977.

[17] TRIP, “Cassava Breeding, Cytogenetics and Histology. Germplasm Enhancement, Root and Tuber Crops Improvement Program,” Archival Report (1989-1993), IITA, Ibadan, 1993, p. 89.

[18] G. H. Bruijn, "Etude de caractere cyanogenetique du manioc (Manihot esculenta Crantz),” Mededelingen Land Bouwhoge School, Wagenigen, Vol. 71, 1971, p. 140.

[19] J. B. Mason and M. Garcia, "Micronutrient Deficiencythe Global Situation,” SCN News, Vol. 9, 1993, pp. 1116.

[20] R. M. Welch, G. F. Combs Jr. and J. M. Duxbury, “Toward a 'Greener' Revolution," Issues in Science and Technology, Vol. 14, 1997, pp. 50-58.

[21] WHO, “Malnutrition Worldwide,” Geneva, 1999, pp. 113. http://www.who.int/nut/malnutrition_worldwide.htm

[22] B. Caballero, "Global Patterns of Child Health: The Role of Nutrition," Annuals of Nutrition and Metabolism, Vol. 46, No. 1, 2002, pp. 3-7. doi:10.1159/000066400

[23] WHO, "Reducing Risks, Promoting Healthy Life,” The World Health Report, World Health Organization, Geneva, 2002, pp. 1-168.

[24] A. J. A. Buitrago, "La Yuca en la Alimentaci on Animal," Centro Internacional de Agricultura Tropical (CIAT), 
Cali, 1990, p. 446.

[25] L. Babu and S. R. Chatterjee, "Protein Content and Amino Acid Composition of Cassava Tubers and Leaves," Journal of Root Crops, Vol. 25, No. 20, 1999, pp. 163168.

[26] C. H. Hendershot, "A Literature Review and Research Recommendations on Cassava (Manihot esculenta Crantz)," University of Georgia, Athens, 1972.

[27] H. E. Bouis, "Enrichment of Food Staples through Plant Breeding: A New Strategy for Fighting Micronutrient Malnutrition,” Nutrition, Vol. 16, No. 7, 2000, pp. 701704. doi:10.1016/S0899-9007(00)00266-5

[28] G. F. Combs Jr., R. M. Welch, J. M. Duxbury, N. T. Uphoff and M. C. Nesheim, "Food-Based Approaches to Preventing Micronutrient Malnutrition: An International Research Agenda,” Cornell University, Ithaca, 1996, pp. $1-68$.

[29] R. M. Welch and R. D. Graham, "A New Paradigm for World Agriculture: Meeting Human Needs,” Field Crops Research, Vol. 60, No. 1-2, 1999, pp. 1-10. doi:10.1016/S0378-4290(98)00129-4

[30] G. Subbulakshmi and M. Naik, "Food Fortification in Developing Countries-Current Status and Strategies,” Journal of Food Science and Technology, Vol. 36, 1999, pp. 371-395.

[31] R. Yip, “The Challenge of Improving Iron Nutrition: Limitations and Potentials of Major Intervention Approaches," European Journal of Clinical Nutrition, Vol. 51, No. 5, 1997, pp. S16-S24.

[32] C. S. Lin and L. P. Lefkovitch, "Stability Analysis: Where Do We Stand?” Crop Science, Vol. 26, No. 5, 1986, pp. 894-900.

[33] Finlay and Wilkinson, "The Analysis of Adaptation in Plant-Breeding Programme,” Australian Journal of Agriculture Research, Vol. 14, No. 6, 1963, pp. 742-754.

[34] Eberhart and Russell, "Stability Parameters for Comparing Varieties,” Crop Science, Vol. 6, 1966, pp. 36-40.

[35] G. H. Freeman, "Statistical Methods for the Analysis of Genotype-Environment Interactions,” Heredity, Vol. 31,
1973, pp. 339-354.

[36] M. Chakroun, C. M. Tliaferro and R. W. McNew, "Genotype-Environment Interactions for Bermuda Forage Yields," Crop Science, Vol. 30, 1990, pp. 49-53. doi:10.2135/cropsci1990.0011183X003000010011x

[37] F. N. Wachira, W. Ng'etich, J. Omolo and G. Mamati, "Genotype-Environment Interactions for Tea Yields," Euphytica, Vol. 127, No. 2, 2002, pp. 289-296. doi:10.1023/A:1020273616349

[38] M. D. Casler and A. W. Hovin, "Genotyp-Environment Interaction for Reed Canary Grass Forage Yield," Crop Science, Vol. 24, 1984, pp. 633-636. doi:10.2135/cropsci1984.0011183X002400040002x

[39] NARAPR, "The Picrate Test in Cassava: A Rapid Assay for Cyanogenic Potential Manual, National Roots and Tuber Crops Programme,” Namulonge Agricultural Research and Animal Production Research Institute, Kampala, 2004.

[40] "Approved Methods of the American Association of Cereal Chemists (AACC),” Method, Vol. 2, 1983, p. 44

[41] J. R. Okalebo, K. W. Gathua and P. L. Woomer, "Laboratory Methods of Soil and Plant Analysis,” Working Manual, Second Edition, 2002.

[42] SAS Institute, Inc., “JMP. Version 3.1,” Cary, North, 1995, Carolina.

[43] A. L. Chavez, T. Sanchenz and H. Caballos, "Variation in Quality Traits in Cassava Roots Evaluated in Land Races and Improved Clones,” Euphytica, Vol. 143, 2005, pp. 125-133. doi:10.1007/s10681-005-3057-2

[44] A. G. O. Dixon, G. N. Ssemakula and J. Mkumbira, "Genetic Enhancement of Beta-Carotene, Iron and Zinc Contents in Cassava for Alleviating Micronutrient Deficiency," Proceedings of the African Crop Science Conference, 2005, pp. 169-173.

[45] J. O. Lorenzo, M. T. B. Ramos and T. L. Valle, "Cyanide Contents in Cassava Cultivars Used for Consumption in the State of Sao Paulo," Braganita, Vol. 52, 1993, pp. $1-5$. 